\section{Passive Movements of Newly Formed Acro- genous Spores in Verticillium and Some Other Genera of the Hyphomycete Fungi}

THE development of the spores in two species of Verticillium, namely, V. Malthousei Ware and $V$. psalliotce Treschow, both parasitic on the cultivated mushroom Psalliota sp., was reported by Treschow ${ }^{1}$ to be different. He observed the spores of $V$. psalliotoe lying transversely across the tips of the phialides on which they were developed. He concluded from this observation that the spores, which originated as a minute globule, grew out on either side perpendicular to the long axis of the phialide. $\mathrm{He}$ did not observe this transverse arrangement in V. Malthousei Ware, and neither did Ware ${ }^{2}$ himself. It was, however, recorded in illustrations of this fungus by Atkins and Bulloch $^{3}$. My own observations from time to time confirmed this record. More recently, I decided to compare the development of the spores in both these species under similar conditions, by continuous observation, using a moist chamber placed on slide cultures.
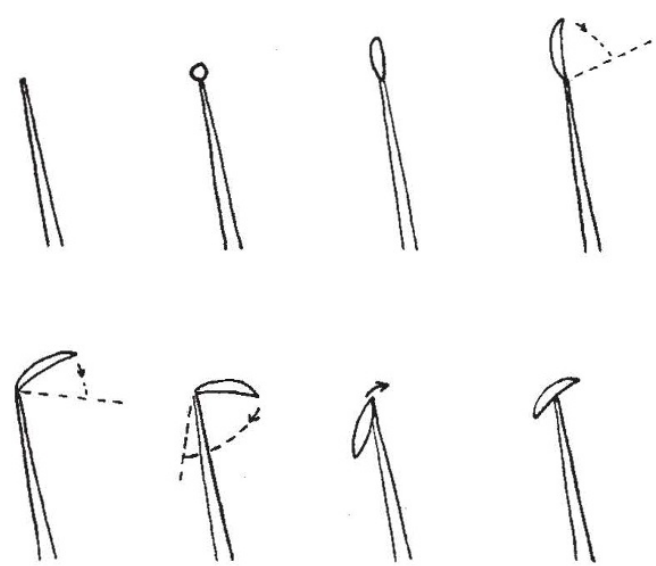

SEQUENCE OF EVENTS OCCURRING DURING SPORE DEVELOPMENT IN Verticillium psalliotoe TRESCH. (DLAGRAMMATIC)

In both V. Malthousei and V. psallioto the spores develop similarly. They appear first as a globule at the tip of the phialide and then elongate, usually in the long axis of the phialide, but sometimes obliquely until they attain approximately their full size and shape and contain a central vacuole. Spore development up to this stage lasts about one hour. The spore then tilts over gradually to form with the long axis of the phialide an angle of about $120^{\circ}$. Eventually, it continues to tilt, but more rapidly, sometimes even suddenly, to an angle of $90^{\circ}$ or less. Then, after a short interval, while remaining in the plane perpendicular to the long axis of the phialide, it suddenly describes an are through an angle of $90^{\circ}$, but sometimes $180^{\circ}$, and then almost immediately slips across the tip of the phialide to lie in the transverse position recorded by Treschow for $V$. psalliotce and by Atkins and Bulloch in their illustrations of sporing phialides of $V$. Malthousei. In agreement with these various authors, I observed that in $V$. Malthousei many spores developed in succession at the tip of the same phialide, the first formed becoming levered out of its horizontal position by the second spore, which followed later. 'These spores remained clustered together in a drop of fluid. In the case of $V$. psalliotce I have not so far observed the formation of more than one spore at the tip of each phialide, except in an isolated instance where two were formed in succession.

These spore movements which I have described for two species of Verticillium explain the misinterpretation by Treschow of the transverse position of the spore relative to the phialide in $V$. psalliotoe and the uninterpreted illustrations of V. Malthouse $i$ by Atkins and Bulloch.

From preliminary observations of spore development in some other genera of Hyphomycetes bearing non-pedicellate spores, notably Cylindrocarpon, Fusarium and the Clonostachys form of Gliocladium, it seems that movements of a similar nature and occurring in the same sequence are not confined to the genus Verticillium but probably occur in many other genera. I have, however, observed movements of a different nature often occurring in Cylindrocarpon and in Fusarium as an alternative to those I have described. C. J. LA TOUCHE

Mushraom Research Association, Ltd.,

Yaxley, Peterborough. July 24.

${ }^{1}$ Treschow, C., Dansk."Bot. Arkiv., 11, Nr. 1,1 (1941).

${ }^{2}$ Ware, W. M., Ann. Bot., 47, No. 188 (1933).

"Atkins, F. C., "Verticillium on Mushrooms" (Midland Group of Mushroom Growers, Yaxley, Peterborough, 1945).

\section{Regulation of the Sodium-Potassium Ratio in Insects}

THE variability of the sodium-potassium ratio in the colomic fluid of different species of insects and its association with the normal diet has been pointed out in previous papers ${ }^{1,2}$ : the vegetarians having a high potassium concentration, the carnivorous insects a high sodium concentration in their colomic fluid.

In order to ascertain the nature of this association, the following hypotheses were tested: (1) The sodium-potassium ratio of the food might have a direct influence on the composition of the cœlomic fluid through lack of regulatory mechanisms in the insects. This possibility was suggested by the similarity between the sodium-potassium ratio of the cœlomic fluid and that of the diet ; thus it is greater than 1 in the carnivorous insects and in animal fluids, less than 1 in vegetarian insects and in plant cells and saps. Carnivorous insect (Calliphora erythrocephala) and vegetarian insects (Ephestia Kühniella, Pieris rapoe and Vanessa urtica) were raised from young to full-grown larvæ on diets with modified sodium-potassium ratio, all other factors being equal. This was done either by dialysing meat and wheat flour against solutions of various ionic TABLE 1. NA/K REgULATION IN THE COELOMIO FLUID OF INSECTS

\begin{tabular}{|c|c|c|c|c|}
\hline \multirow{2}{*}{ Insects and diets } & \multicolumn{3}{|c|}{ Ions concentration in equiv./kgm. } \\
\cline { 2 - 5 } & \multicolumn{2}{|c|}{ In the diet } & \multicolumn{2}{c|}{ In colomic fluid } \\
\cline { 2 - 5 } & $\mathrm{Na}$ & $\mathrm{K}$ & $\mathrm{Na}$ & $\mathrm{K}$ \\
\hline Calliphora erythrocephala & 0.082 & 0.007 & 0.158 & 0.037 \\
(6 days on dialysed meat) & 0.010 & 0.111 & 0.083 & 0.040 \\
\hline \multirow{2}{*}{ Ephestia Kühniella } & 0.098 & 0.011 & 0.030 & 0.047 \\
(35 days on dialysed flour) & 0.098 & 0.011 & 0.027 & 0.056 \\
& 0.008 & 0.115 & 0.016 & 0.059 \\
& 0.008 & 0.115 & - & 0.065 \\
\hline \multirow{2}{*}{ Pieris rapae } & 0.006 & 0.077 & 0.010 & 0.075 \\
(5 days on cabbage) & 0.006 & 0.077 & 0.013 & 0.074 \\
& 0.027 & 0.061 & 0.009 & 0.080 \\
& 0.027 & 0.061 & 0.010 & 0.077 \\
\hline Vanessa urtica, 2 days on : & 0.010 & 0.100 & 0.022 & 0.043 \\
Leaves & 0.366 & 0.088 & 0.058 & 0.049 \\
Leaves coated with NaCl & 0.010 & 0.700 & 0.021 & 0.080 \\
Leaves coated with KCl & 0.00 & & & \\
\hline
\end{tabular}

